\title{
Pelatihan ICT Bagi Pelaku Usaha Kecil Menengah (UKM) Kota Solok
}

\author{
Novia Lestari \\ Universitas Mahaputra Muhammad Yamin (UMMY) Solok \\ Jln. Raya Koto Baru Solok, Sumatera Barat \\ Manajemen Informatika \\ Novialestari@ummy.ac.id
}

\begin{abstract}
ABSTRAK
Usaha Mikro Kecil Menengah merupakan salah satu sektor penting yang mendukung pertumbuhan ekonomi Indonesia saat ini. Tidak hanya muncul di kota-kota besar, geliat UKM juga tumbuh dan berkembang di daerah-daerah. Pertumbuhan UKM sendiri juga terasa di Kota Solok Provinsi Sumatera Barat. Namun seiring banyaknya UKM yang terdapat di Kota Solok, membuat dinas terkait sulit untuk mengcover seluruh data maupun kebutuhan dari semua UKM yang ada. Dari berbagai kegiatan pelatihan dan pembinaan yang telah disediakan oleh dinas ini, belum mampu menampung dan memfasilitasi seluruh kelompok-kelompok UKM yang ada. Sehingga masih banyak UKM yang belum tersentuh fasilitas bantuan maupun pembinaan dari dinas terkait, yang berdampak pada kurang maksimalnya manajemen usaha dan kelangsungan usaha UKM-UKM tersebut. Metode pelaksanaan dimulai dengan diskusi awal dengan Mitra untuk mengetahui kebutuhan kelompok-kelompok UKM dan menetukan solusi yang tepat dalam mengatasi permasalahan yang ada, memfasilitasi kelompok-kelompok UKM dengan pembinaan manajemen usaha, dan administrasi serta pelatihan pemanfaatan teknologi sehingga mampu memberikan nilai tambah dalam segi income maupun wawasan bagi kelompok-kelompok UKM yang ada di Kota Solok.
\end{abstract}

Kata kunci: Usaha Kecil Menengah, Manajemen Usaha, Promosi

\begin{abstract}
Micro, Small and Medium Enterprises are one of the important sectors that support Indonesia's economic growth today. Not only appears in big cities, stretching SMEs also grows and develops in the regions. The growth of SMEs themselves is also felt in the City of Solok, West Sumatra Province. But along with the number of SMEs located in the city of Solok, making related agencies difficult to cover all data and the needs of all existing SMEs. From the various training and coaching activities that have been provided by this agency, it has not been able to accommodate and facilitate all existing SME groups. So that there are still many SMEs that have not been touched by assistance or coaching facilities from related agencies, which has an impact on the lack of business management and business continuity of these SMEs. The implementation method begins with an initial discussion with Partners to find out the needs of SME groups and determine the right solution to overcome existing problems, facilitate SME groups with business management guidance, and administration and training on technology utilization so as to provide added value in terms of income as well as insights for SME groups in Solok City.
\end{abstract}

Keywords: Small and Medium Enterprises, Business Management, Promotion

\section{PENDAHULUAN}

Usaha Mikro Kecil dan Menengah (UMKM) merupakan salah satu roda penggerak perekonomian Indonesia akhir-akhir ini, dimana jenis-jenis usaha yang tergabung dalam kelompok UKM mampu memberikan profit serta keuntungan yang besar tidak hanya bagi pegiat usaha itu sendiri tapi juga menyumbang devisa negara yang signifikan (Hapsari,2014). Terbukti ketika krisis moneter yang terjadi pada tahun 1997 menumbangkan banyak perusahaan-perusahaan besar, namun bisnis UMKM justru menjadi 
penyelamat bagi perekonomian masyarakatIndonesia (Saepulloh,2017). Menurut Kementerian Koperasi dan UKM, bahwa kontribusi UKM terhadap Produk Domestik Regional Bruto (PRDB) dalam tiga tahun terakhir tercatat tumbuh sangat baik hingga mencapai 60 persen. Hal ini juga membuat geliat UKM semakin tumbuh dan berkembang (Suroyah,2016). Hingga saat ini, menurut data dari Kementerian Koperasi dan UKM, terdapat 59,69 juta unit pelaku UMKM di seluruh Indonesia yang tumbuh dan tersebar di berbagai jenis usaha mikro kecil dan menengah seperti kuliner, fashion, industri manufaktur, dan lainnya, yang memberikan kontribusi yang cukup besar terhadap perekonomian yakni mencapai 61,41\% (Adiputra,2014).

Berdasarkan data yang diperoleh dari Badan Pusat Statistik (BPS) melalui website www.depkop.go.id, pada tahun 2017 wirausahawan di Indonesia meningkat menjadi 3,1 persen atau 7,8 juta orang dibandingkan tahun sebelumnya yang hanya mencapai 1,6 persen. Pertumbuhan UKM sendiri juga terasa di Kota Solok Provinsi Sumatera Barat. Dimana mayoritas penduduk usia produktif bekerja pada lapangan usaha perdagangan dan didominasi oleh pedagang-pedagang kecil yang tergabung dalam kelompok-kelompok UKM binaan Dinas Perdagangan, Koperasi, dan UKM Kota Solok.

Berdasarkan data Dinas Perdagangan, Koperasi, dan UKM Kota Solok, hingga tahun 2017 Kota Solok memiliki 3.336 UKM dengan 9 macam jenis usaha yaitu bidang pertanian, peternakan, kehutanan, dan perikanan, bidang pertambangan dan penggalian, bidang industri pengolahan, bidang listrik, gas, dan air bersih, bidang perdagangan, hotel, dan restoran, bidang pengangkutan dan komunikasi, bidang keuangan, persewaan, dan jasa perusahaan, dan bidang jasa-jasa swasta yang tersebar di 2 kecamatan dan 13 kelurahan, yaitu Kecamatan Lubuk Sikarah (dengan 7 kelurahan) dan Kecamatan Tanjung Harapan (dengan 6 kelurahan) [7]. Dimana masingmasing kelurahan memiliki kelompok UKM dengan jenis usaha yang berbeda, seperti usaha pembuatan makanan tradisional pinyaram di Kelurahan Tanjung Paku, industri rumah tangga Usaha Kerupuk di IX Korong, serta masih banyak usahausaha kreatif lainnya.

Sebagai unsur pelaksana pemerintahan di bagian Perdagangan, Koperasi, dan UKM, Dinas Perdagangan, Koperasi, dan UKM Kota Solok telah melakukan pembinaan kelompok UKM, mengadakan pameran pembangunan dan produksi Kota Solok, serta Bimbingan Teknis (BimTek) bendahara koperasi se Kota Solok. Namun seiring banyaknya UKM yang terdapat di Kota Solok, belum semua kelompok UKM yang mendapat fasilitas bantuan maupun pembinaan dari dinas ini. Keberadaan UKM yang cukup banyak ini, juga membuat dinas terkait sulit untuk mengcover seluruh data maupun kebutuhan dari semua UKM yang ada. Dari berbagai kegiatan pelatihan yang telah disediakan, dinas ini belum mampu menampung dan memfasilitasi seluruh kelompok-kelompok UKM yang ada. Sehingga kami dari tim pengusul mencoba membantu dan 
bekerjasama dengan dinas terkait untuk memfasilitasi pegiat UKM Kota Solok dalam mengoptimalkan pemanfaatan teknologi informasi, baik dalam manajemen usaha maupun promosi UKM dengan cara mengadakan pelatihan, pembinaan, dan pendampingan untuk UKM yang ada, khususnya UKM sektor industri pengolahan.

\section{METODE PELAKSANAAN}

Metode pelaksanaan program kemitraan masyarakat berdasarkan permasalahan manajemen dan pemasaran yang dihadapi mitra adalah sebagai berikut:

1. Diskusi awal dengan Mitra untuk mengetahui kegiatan dan pembinaan yang akan dilakukan dalam menetukan solusi yang tepat dalam mengatasi permasalahankelompok-kelompok UKM binaan yang ada. Pada tahap ini, tim pengusul dan mitra menetapkan tujuan bersama untuk menyelesaikan permasalahan yang ada dengan cara memfasilitasi kelompok-kelompok UKM binaan dengan pelatihan, pendampingan, dan pembinaan sehingga kelompok-kelompok UKM yang ada di Kota Solok bisa berkembang menjadi lebih baik lagi.

2. Pelatihan

a. Pengusul bersama-sama dengan mitra memberikan pelatihan tentang pemanfaatan teknologi informasi berupa penggunaan komputer atau laptop, agar kelompok-kelompok UKM yang ada bisa maksimal dalam penggunaan teknologi informasi termasuk memanfaatkan website yang nantinya dibuat untuk memfasilitasi Dinas Koperindag Kota Solok untuk mengcover seluruh data UKM yang ada, juga menyebarluaskan informasi yang berhubungan dengan UKM-UKM yang ada.

b. Pengusul bersama-sama dengan mitra mengadakan pelatihan dan pembinaan pemanfaatan media sosial sebagai wadah untuk mempromosikan produk UKM agar jangkauan area penjualan yang semula hanya di sekitar lingkungan tempat tinggal saja menjadi lebih luas dan produk UKM lebih dikenal masyarakat luas.

c. Memberikan pembinaan dan pelatihan administrasi dan pembukuan sederhana

\section{Evaluasi dan Pendampingan}

Setelah pelatihan diberikan, tim pengusul bekerjasama dengan mitra akan terus memnberikan pendampingan kepada kelompokkelompok UKM Kota Solok dalam hal manajemen pemasaran maupun promosi, hingga benar-benar dipastikan bahwa output dari kegiatan Program Kemitraan Masyarakat ini benar-benar tercapai. Karena target yang akan dicapai lewat Program Kemitraan Masyarakat ini yakni membantu Dinas Perdagangan, Koperasi, dan UKM Kota Solok (mitra) untuk memfasilitasi pegiat UKM Kota Solok dalam mengoptimalkan pemanfaatan teknologi informasi, baik dalam manajemen usaha maupun promosi UKM dengan cara mengadakan pelatihan, pembinaan, dan pendampingan untuk UKM yang ada, khususnya UKM sektor industri pengolahan. Agar bisa memberikan 
nilai tambah bagi kelompokkelompok UKM yang ada di Kota Solok, baik dalam bidang produksi, manajemen usaha (berupa izin usaha, izin depkes dan label produk), serta pemasaran, mulai dari memfasilitasi dan melakukan pendampingan dalam pemanfaatan teknologi seperti melakukan pendampingan dan membantu dalam pengurusan izin usaha, izin DepKes, dan label halal, merancang packing kemasan agar terlihat lebih menarik, dan berupaya memperluas area pemasaran dengan memanfaatkan akses teknologi melalui promosi dengan media sosial. Sehingga dengan adanya kegiatan PKM ini, mampu mengembangkan produk-produk unggulan hasil UKM agar menjadi produk unggulan daerah yang nantinya memberikan dampak yang baik untuk perekonomian Kota Solok.

\section{HASIL DAN PEMBAHASAN}

Dari tinjauan ke lapangan didapat permasalahan-permasalahan yang dihadapi UKM Kota Solok adalah sebagai berikut :

1. Jiwa kewirausahaan yang masih rendah, sehingga penggiat UKM masih berpikir manja (kurang mandiri) tentang usaha perdagangan maupun industri yang mereka geluti. Sehingga dibutuhkan support, arahan dan pembinaan dari Dinas Koperindag agar kelompok-kelompok UKM binaan bisa terus berkembang jiwa wirausahanya.

2. Fasilitas produksi yang belum mendukung, Packaging kemasan yang belum representative, sehingga mengakibatkan lemahnya daya saing produk UKM yang dihasilkan, serta terbatasnya lahan pasar untuk produk yang dihasilkan UKM.

3. Masih minimnya pengetahuan para penggiat UKM tentang manajemen usaha dan pemanfaatan teknologi, termasuk persoalan perizinan, masalah administrasi dan manajemen keuangan yang belum dikuasai, sehingga diperlukan pengetahuan administrasi dan pembukuan sederhana dengan memberikan pelatihan pencatatan keuangan berdasarkan siklus akuntansi yang Praktis.

4. Dengan jumah UKM yang mencapai 3.336, Dinas Perdagangan, Koperasi, dan UKM belum mampu menampung dan memfasilitasi seluruh kelompokkelompok UKM yang ada, sehingga pencatatan, perekapan data UKM belum terekap secara valid, pelatihan dan pembinaan pun masih merata dan belum maksimal.

Dengan kegiatan PKM yang telah dilakukan, maka didapat adanya nilai tambah bagi industri rumah tangga kelompok-kelompok UKM, dimana mitra memiliki skill wirausaha yang baik dan benar, mempunyai pengetahuan dan wawasan baru tentang pengelolaan manajemen usaha yang baik, seperti mampu dalam pengurusan izin usaha, izin DepKes, dan label halal, bisa merancang packing kemasan agar terlihat lebih menarik, dan mereka sudah mampu berupaya memperluas area pemasaran dengan memanfaatkan akses teknologi melalui promosi dengan media social dengan memanfaatkan teknologi informasi dan social media yang telah diajarkan selama pelatihan dan 
pembinaan. Selain itu, mitra juga mempunyai inisiatif untuk menghasilkan produk baru sebagai hasil usaha, agar yang mampu bersaing dengan industri lainnya dan dapat memperluas penyerapan tenaga kerja dan meningkatkan kesejahteraan hidup nantinya.

\section{KESIMPULAN}

Kegiatan Pengabdian Kepada Masyarakat ini merupakan salah satu kegiatan yang harus rutin dilakukan sebagai wujud Tridarma Perguruan Tinggi. Dengan adanya kegiatan PKM ini diharapkan dapat membantu masyarakat sekitar yang sudah mengarah ke arah produktif ekonomi, sehingga masyarakat memiliki budaya wirausaha dan menjadi agen perubahan yang tidak hanya berusaha mencari pekerjaan tapi menciptakan lapangan pekerjaan.

Dengan berbagai pelatihan dan pembinaan yang telah diberikan, diharapkan masyarakat lebih kreatif dan inovatif lagi dalam berwirausaha, sehingga usaha-usaha kecil sekalipun mampu bersaing dengan usaha skala besar di luar sana.

\section{REFERENSI}

Adiputra, E. (2014). "Pentingnya Jiwa Kewirausahaan Pengelola Koperasi". Seminar

Kewirausahaan Bagi Pengurus Koperasi. Jatim: Bank UMKM.

Badan Pusat Statistik (BPS). 2008. Perusahaan Industri Pengolahan. Badan Pusat Statistik. Jakarta.
Hapsari, Ira Maya (2014), "Identifikasi Berbagai Permasalahan Yang Dihadapi Oleh UKM Dan Peninjauan Kembali Regulasi UKM Sebagai Langkah Awal Revitalisasi UKM". Jurnal PERMANA, Volume : V, Nomor $: 2$

Mas, V. H., M.R Yantu., dan Dafina Howara. 2013. Prospek Pengembangan Usaha Pada Industri Rumah Tangga Kacang Telur "Ohara" Kota Palu. e-J. http://download.Portal garuda.org/

Mawaddah, A. M. 2013. Distribusi Spasial Dan Karakteristik Industri Rumah Tangga Pangan Di Kecamatan Ungaran Barat. Skripsi. Semarang: Fakultas Ilmu Sosial Universitas Negeri Semarang. http://lib.unnes.ac.id/.

Saepulloh, Luthpi dan Sofiani, Venita (2017), "Keanekaragaman Sumber Penghasilan Masyarakat Dalam Rangka Peningkatan Kualitas Hidup Dan Pengentasan Keluarga Prasejahtera". Jurnal Ilmiah Ilmu Ekonomi, Volume : 5, Nomor : 10, ISSN : 20886969.

Suroyah, I. A. 2016. Analisis FaktorFaktor Yang Mempengaruhi Nilai Produksi Industri Kecil Tenun Ikat Di Kabupaten Jepara Jawa Tengah (Studi Kasus di Desa Troso Kecamatan Pecangaan Kabupaten Jepara). Skripsi. Yogyakarta: Fakultas Ekonomi Universitas Negeri Yogyakarta. http://eprints.uny.ac.id/. 
Amaliah: Jurnal Pengabdian Kepada Masyarakat Volume 2 No. 2 November 2018

Undang-Undang Republik Indonesia Tentang Usaha Mikro, Kecil dan Menengah Nomor 20 Tahun 2008

Yuniartini, Sri. 2013. Pengaruh Modal, Tenga Kerja dan
Teknologi terhadap Produksi Industri Kerajinan Ukiran Kayu di Kecamatan Ubud. E-Jurnal Ekonomi Pembangunan Universitas Udayana, 2 (2), h: 95-101. 